\title{
Application of Kano Model in Requirements Analysis of Y Company's Consulting Project
}

\author{
Jiawen Huang \\ School of Management, Jinan University, Guangzhou, China \\ Email: huangjiawen_17@163.com
}

How to cite this paper: Huang, J.W. (2017) Application of Kano Model in Requirements Analysis of Y Company's Consulting Project. American Journal of Industrial and Business Management, 7, 910-918. https://doi.org/10.4236/ajibm.2017.77064

Received: June 14, 2017

Accepted: July 10, 2017

Published: July 13, 2017

Copyright $\odot 2017$ by author and Scientific Research Publishing Inc. This work is licensed under the Creative Commons Attribution International License (CC BY 4.0).

http://creativecommons.org/licenses/by/4.0/

\begin{abstract}
With the intense competition, more and more companies become customer-oriented instead of business-oriented, especially in service industries. How to elicit customer requirements is vital to improve service quality. But as an invisible product, service is lack of quantifiable physical index, so it is difficult to standardize the measure of service quality. Therefore, to elicit and analyze customer requirements and improve customer satisfaction are tough tasks. Using the Kano Model to analyze and classify the requirements of $\mathrm{Y}$ Company's consulting project, we recognize the effective factors in improving Y Company's satisfaction, and make certain suggestions for consulting company to improve its service quality.
\end{abstract}

\section{Keywords}

Kano Model, Management Consulting Services, Requirements Analysis

\section{Introduction}

Management consulting is the practice of helping organizations to improve their performance, operating primarily through the analysis of existing organizational problems and the development of plans for improvement. Organizations may draw upon the services of management consultants for a number of reasons, including gaining external (and presumably objective) advice and access to the consultants' specialized expertise [1]. Management consulting was born in the late 19th century and first developed in the United States. In China, management consulting industry began to develop in 1980s, mainly in the fields of investment, technology and finance. With the economic development in China, management consulting industry has been booming in these years and appears two major trends. First of all, the customer's expectation of consulting service is becoming higher. Secondly, the competition among consulting enterprises is more and more intense due to the increasing number of competitors [2]. 
Under this background, there is an increasing need for consulting companies to put a high value on capturing and analyzing customer requirements in order to win the market. Considering customer requirements late in consulting service is responsible for the poor quality of consulting solutions today. Some state that having a good grasp of customer requirements plays a vital role in the success of the consulting project [3] [4] [5]. Homburg (2013) claims that adverse effect of neglecting requirement problems would be further intensified in subsequent phases of the consulting service, thus it would cause the omission of important solutions, inclusion of irrelevant features, costly reworks, project delay and even, losing the market because customers' needs are not met [6].

One of the ways of looking into the concerns of customer requirements early to provide outstanding service in consulting is to begin with the elicitation of requirements that delight and satisfy the clients [7]. Requirements elicitation is the process of capturing and determining client's requirements for a consulting service, that results in high probability of satisfying the client's needs. To capture what customers' satisfaction/dissatisfaction will be if the requirements/features are met/unmet, Kano method is proposed to be used. Kano model helps to extract from customers what they really expect from a product/service. Using this model, proposed features that most stimulate customers are captured; hence, enabling the building of a unique and lean product/service that contains the necessary features that pleases and amazes the customers [7] [8].

The main objective of this study is to elicit Y Company's satisfying requirements of the consulting service employing Kano Model. Kano model is a popular technique in the interdisciplinary field of quality management, but it is rarely applied in consulting service research. Moreover, analyzing Y Company's requirements could be a reference to other consulting projects, which would help consultants to provide satisfactory service. This paper is divided into six sections: Section 1, introduction; Section 2, literature review; Section 3, methodology; Section 4, results; Section 5, discussion and Section 6, conclusions.

\section{Literature Review}

\subsection{Kano Method}

Kano et al. (1984) proposed the Kano Model based on Herzberg's "MotivationHygiene" Two Factor Theory [9]. The model measures customers' feeling and the impact of product/service quality on their perceived satisfaction. It defines the different classifications of product/service quality attributes/features that have influence on customer satisfaction. While customer's need is met, there is customer satisfaction or just no feeling of dissatisfaction. Also, while customer's need isn't met, there is customer dissatisfaction or just no feeling of satisfaction. It is a two-dimensional model that views the relationship between quality and customer satisfaction as nonlinear [9].

\subsection{Kano Model Categories}

Kano et al. (1984) showed that not all requirements are at equal level of impor- 
tance from the viewpoint of the customer [9]. Kano model of customer satisfaction defines the relationship between product/service attribute and customer satisfaction and provides five types of attributes:

1) "Must-Be" requirement is a basic requirement, of which its absence leads to customer extreme dissatisfaction, the customer takes this requirement for granted, thus, their being met does not increase the satisfaction level of customers. Meeting this requirement leads to a state of "not dissatisfied".

2) "One-Dimensional" requirement, which is a linear kind of requirement, when met, the satisfaction of the customer is increased, but when unmet, the satisfaction level of the customer is decreased, that is their dissatisfaction increases. This requirement/feature is what the customers expect from the proposed product/service. It is a performance requirement. These requirements are usually demanded by customers.

3) "Attractive" requirement is a kind of nice to have requirement. Without it, there is actually no problem (there is no feeling of dissatisfaction), but having it will maximize the level of satisfaction (that is, it leads to more than proportional satisfaction if met). These requirements are the features that have the greatest impact on the level of customer satisfaction.

4) "Indifference" requirement, a no preference requirement, implying that the customer is indifferent to the requirement/feature. He does not care if the feature is present or not.

5) "Reverse" requirement, an inverse requirement (can be either way), here, the customer expectation about the feature in a reverse order.

In addition to these five categories, there is one more requirement called "Questionable", which indicates a wrong answer from the customer filling the questionnaire which renders the response invalid [10] [11]. Figure 1 below is the Kano Model.

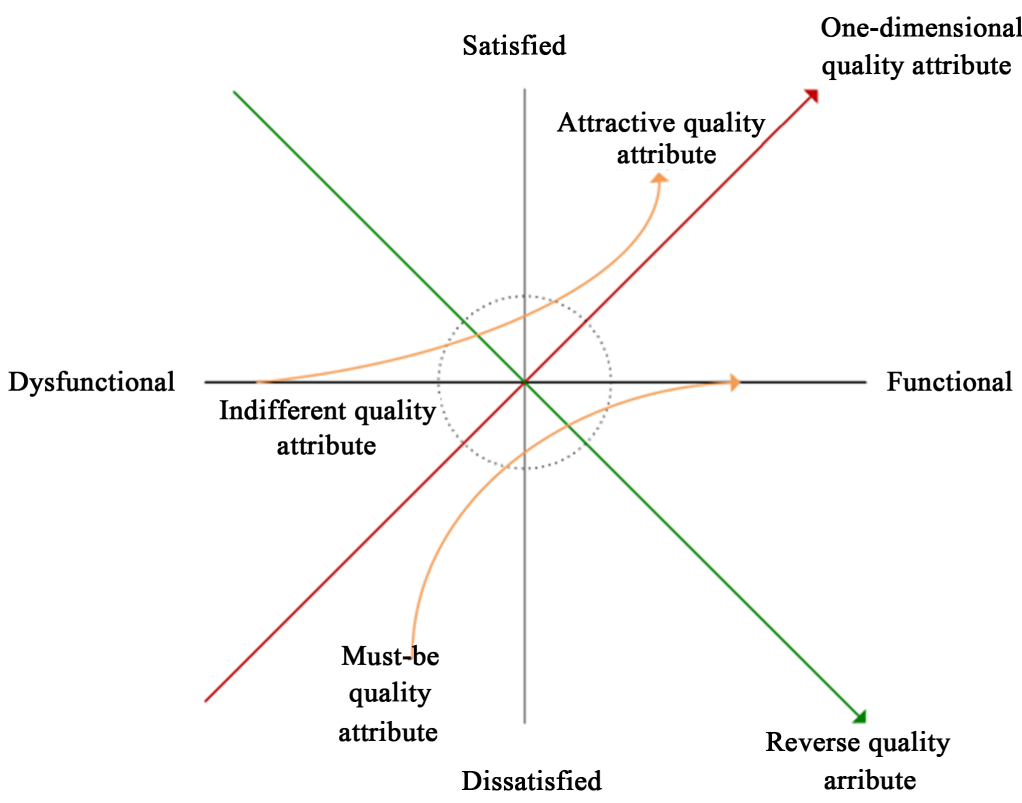

Figure 1. Kano's two-dimensional model. 


\subsection{Kano Questionnaire}

The Kano Model incorporates a survey instrument that overcomes the bias arising from the traditional requirement elicitation survey instrument. To implement Kano model, a two-dimensional questionnaire is prepared for each product/service attribute. The first question is functional (a positive question) and the second is dysfunctional (a negative question). The first question is asked to find out how the customers feel if the proposed feature is in place or requirement is met while the second question is to find out how they feel if the intended feature is not in place or requirement is not met.

Each of the questions (whether functional or dysfunctional), has a list of five options, namely: 1. "I like it that way" (like), 2. "It must be that way" (must-be), 3. "I am neutral" (neutral), 4. "I can live with it that way" (live with), 5. "I dislike it that way" (dislike). After the survey, the result is tallied and totaled to show how the majority of customers expressed their requirements, and this is categorized into M "Must-Be", O “One-Dimensional”, A “Attractive”, I "Indifferent", $\mathrm{R}$ "Reverse" and $\mathrm{Q}$ "Questionable" categories. The rule for evaluation is: " $\mathrm{M}>$ $\mathrm{O}>\mathrm{A}>\mathrm{I}$ ". This rule guides decisions when making decisions on which feature/ requirement has more influence on the perceived quality of the proposed product/service [10] [11].

All possible combinations of customer answers and the corresponding type of product attribute are summarized in following Table 1.

\subsection{Coefficient of Customer Satisfaction}

Berger et al. (1993) proposed the coefficient of satisfaction in 1993, which indicates whether meeting a requirement, the level of customer satisfaction can be increased or whether meeting the requirement just hinders the customer from being dissatisfied [12]. The coefficient of satisfaction (CS) is calculated as follow [12]:

$$
\begin{aligned}
& \mathrm{SI}=(\mathrm{A}+\mathrm{O}) /(\mathrm{A}+\mathrm{O}+\mathrm{M}+\mathrm{I}) \\
& \mathrm{DI}=(\mathrm{M}+\mathrm{O}) /(\mathrm{A}+\mathrm{O}+\mathrm{M}+\mathrm{I})
\end{aligned}
$$

where SI is the extent of Satisfaction, DI is the extent of Dissatisfaction, A is Attractive, $\mathrm{O}$ is One Dimensional, $\mathrm{M}$ is Must-Be and I is Indifferent. After calcu-

Table 1. Kano evaluation.

\begin{tabular}{cccccc}
\hline \multirow{2}{*}{ Functional } & \multicolumn{5}{c}{ Dysfunctional } \\
\cline { 2 - 6 } & Like & Must-be & Neutral & Live-with & Dislike \\
\hline Like & $\mathrm{Q}$ & $\mathrm{A}$ & $\mathrm{A}$ & $\mathrm{A}$ & $\mathrm{O}$ \\
Must-be & $\mathrm{R}$ & $\mathrm{I}$ & $\mathrm{I}$ & $\mathrm{I}$ & $\mathrm{M}$ \\
Neutral & $\mathrm{R}$ & $\mathrm{I}$ & $\mathrm{I}$ & $\mathrm{I}$ & $\mathrm{M}$ \\
Live-with & $\mathrm{R}$ & $\mathrm{I}$ & $\mathrm{I}$ & $\mathrm{I}$ & $\mathrm{M}$ \\
Dislike & $\mathrm{R}$ & $\mathrm{R}$ & $\mathrm{R}$ & $\mathrm{R}$ & $\mathrm{Q}$ \\
\hline
\end{tabular}

$\mathrm{A}=$ Attractive, $\mathrm{I}=$ Indifferent, $\mathrm{M}=$ Must-be, $\mathrm{O}=$ One-dimensional, $\mathrm{Q}=$ Questionable, and $\mathrm{R}=$ Reverse. 
lating the results of SI and DI, we could create Coordinate System in which, $\mathrm{X}$-coordinate is for SI and Y-coordinate is for DI. Each quality attribute could be assigned to different quadrants of the coordinate axis, which corresponds to different Kano type. Figure 2 below shows the Coordinate System and the Kano type.

\section{Methodology}

\subsection{Background of Y Company}

Based in Guangzhou, Y Company was founded in 1993, concentrating on designing and constructing highways. Y Company has a single business, with 98.41\% of its revenue and $99.19 \%$ of its profits coming from highway operation. A few decades ago, because of the fast development of highway construction in China, Y Company was in a period of rapid development. However, with the layout of highways gradually being improved, growth of Y Company has slackened off, therefore it plans to expand new business.

However, with traditional management system which seriously hinders $\mathrm{Y}$ Company's expansion, there is an increasing need for Y Company to improve its management. Therefore, Y Company decides to cooperate with consulting companies, who would find a solution to solve its problems. To Y Company, the consulting project is the product/service which it wants to purchase.

\subsection{Y Company's Requirements of Consulting Project}

Among the research focusing on customer satisfaction of consulting project, some believe that whether the consulting solutions fully take into account the clients' situation as well as the regular communication with consultants is the most important thing that the clients concern about [13]. Liu (2009) claims several factors which are significant to customers in consulting service, including project cost, professional and feasible solutions, consultants' experience and onsite service, the qualification and the industry positions of consulting companies and assistance on the implementation of solutions [2]. Moreover, Wu (2016) proposes the experience and the number of the consultants for the project would contribute to customer satisfaction [14].



Figure 2. Coordinate system of the Kano type. 
After browsing related literature, conducting field research and questionnaires, 18 requirements/features were elicited and evaluated in this study. They include:

R1: Adaptability, the consulting solutions should adapt to Y Company's current situation.

R2: Compatibility, the consulting solutions should be compatible with the new business of Y Company.

R3: Feasibility, the consulting solutions should be feasible in Y Company.

R4: Comprehensiveness, the consulting solutions should be comprehensive to cover the necessary parts.

R5: Variety, the consulting solutions should be varied in order for Y Company to select the best one.

R6: Professionalization, the consulting solutions should be professional.

R7: Punctuality, the consulting service should be punctual based on the schedule.

R8: Regular reporting, the consultants should report to Y Company in different stage regularly.

R9: Moderate solutions, the consulting solutions should be moderate enough to the company.

R10: Assist, the consultants should assist the implementation of the solutions.

R11: Consistency, the solutions should be consistent with the opinions of Y Company's executives.

R12: Industry positions, the industry positions of the consulting company.

R13: The site, the site of the consulting company should near Y Company.

R14: Price, the price of the consulting project should be under the budget.

R15: Qualification, the consulting company should have a good qualification.

R16: Experience, the consultants should be experienced in consulting.

R17: On-site service, the consultants provide on-site consulting service.

R18: Number of consultants for the project.

These requirements are the main requirements/features expected to be incorporated in the consulting service of Y Company.

In this paper, Kano Mode land the extension of Kano Model were used for data collection and analysis as well as in the categorization of requirements. In this case, Y Company is the customer of the consulting project. That is to say, the staff and managers in Y Company are the customers that we want to analyze. A Kano questionnaire was constructed and administered to a forty-one (41) respondents during the Kano survey. The participants were staff and managers of Y Company. The questionnaire used a 5-point Like-type rating scale that ranges from like to dislike based on Kano questionnaire. And finally, all questionnaires were collected.

\section{Results}

\section{Kano Analysis}

Table 2 reveals the extent of users' satisfaction and dissatisfaction with 
Table 2. The results of Kano's questionnaire analysis.

\begin{tabular}{|c|c|c|c|c|c|c|c|c|c|}
\hline Req & $\mathbf{M}$ & $\mathrm{O}$ & A & I & $\mathbf{R}$ & Q & $\mathrm{T}$ & $\mathrm{Si}$ & $\mathrm{Di}$ \\
\hline $\mathrm{R} 1$ & 23 & 12 & 4 & 2 & 0 & 0 & 41 & 0.390243902 & 0.853658537 \\
\hline $\mathrm{R} 2$ & 24 & 11 & 4 & 1 & 0 & 1 & 41 & 0.375 & 0.875 \\
\hline $\mathrm{R} 3$ & 31 & 6 & 3 & 1 & 0 & 0 & 41 & 0.219512195 & 0.902439024 \\
\hline $\mathrm{R} 4$ & 27 & 3 & 5 & 4 & 1 & 1 & 41 & 0.205128205 & 0.769230769 \\
\hline $\mathrm{R} 5$ & 29 & 4 & 7 & 1 & 0 & 0 & 41 & 0.268292683 & 0.804878049 \\
\hline R6 & 15 & 4 & 1 & 20 & 1 & 0 & 41 & 0.125 & 0.475 \\
\hline $\mathrm{R} 7$ & 13 & 9 & 14 & 3 & 0 & 2 & 41 & 0.58974359 & 0.564102564 \\
\hline $\mathrm{R} 8$ & 30 & 10 & 1 & 0 & 0 & 0 & 41 & 0.268292683 & 0.975609756 \\
\hline R9 & 10 & 29 & 2 & 0 & 0 & 0 & 41 & 0.756097561 & 0.951219512 \\
\hline R10 & 32 & 8 & 1 & 0 & 0 & 0 & 41 & 0.219512195 & 0.975609756 \\
\hline R11 & 3 & 8 & 6 & 21 & 2 & 1 & 41 & 0.368421053 & 0.289473684 \\
\hline $\mathrm{R} 12$ & 25 & 8 & 2 & 4 & 1 & 1 & 41 & 0.256410256 & 0.846153846 \\
\hline $\mathrm{R} 13$ & 26 & 9 & 3 & 3 & 0 & 0 & 41 & 0.292682927 & 0.853658537 \\
\hline R14 & 20 & 13 & 4 & 3 & 0 & 1 & 41 & 0.425 & 0.825 \\
\hline $\mathrm{R} 15$ & 19 & 17 & 4 & 1 & 0 & 0 & 41 & 0.512195122 & 0.87804878 \\
\hline R16 & 17 & 20 & 2 & 2 & 0 & 0 & 41 & 0.536585366 & 0.902439024 \\
\hline R17 & 7 & 9 & 19 & 5 & 1 & 0 & 41 & 0.7 & 0.4 \\
\hline $\mathrm{R} 18$ & 5 & 13 & 3 & 16 & 3 & 1 & 41 & 0.432432432 & 0.486486486 \\
\hline
\end{tabular}

A (Attractive); O (One-Dimensional); M (Must-Be); I (Indifference); R (Reverse); Q (Questionable); T (Total); Req, R1-R18 (Requirements).

regards to when the requirements are met and unmet respectively. Creating Coordinate System in which, X-coordinate is for SI and Y-coordinate is for DI, would help us to figure out the importance of the requirements.

As illustrated in the previous section, the requirements in first quadrant stand for one-dimensional requirements, the requirements in second quadrant stand for must-be requirements, the requirements in third quadrant stand for indifference requirements; and those in forth quadrant stand for attractive requirements. Therefore, Figure 3 shows the categorization of each requirement. The categorizations of requirements are as follows:

Must-be requirements: R1, R2, R3, R4, R5, R8, R10, R12, R13, R14;

One-dimensional requirements: R7, R9, R15, R16;

Attractive requirements: R17;

Indifference requirements: R6, R11, R18.

\section{Discussion}

As can be seen from the analysis offered in the study, customer requirements were elicited. This study shows that for the consulting service of Y Company, most of the requirements should be must-be requirements and one-dimensional requirements in order to maximize the service quality. In addition, there are 


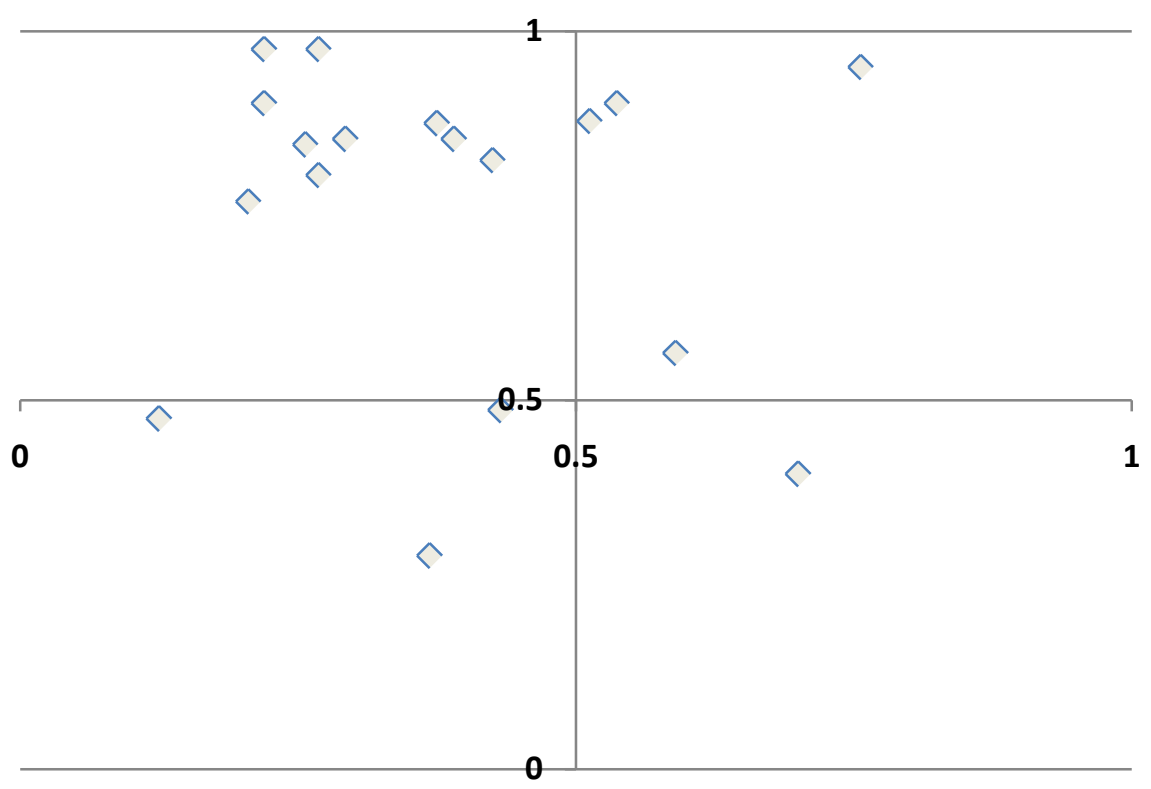

Figure 3. Coordinate system of requirements.

some indifference requirements which should not be considered during the service to Y Company.

The most important factors that influence Y Company's satisfaction of consulting service are as follows: (1) for a consulting solution, instead of being professional, Y Company is more interested in whether it would be suitable and feasible for the company, as well as its comprehensiveness, compatibility and variety; (2) corporation characteristics are the factors that $\mathrm{Y}$ Company concerns about, such as industry position and site; (3) the project quotation must be under the budget. Moreover, the features including punctuality, moderate solutions, qualification and experience should be improved as they have linear correlation with Y Company's satisfaction. In addition, providing on-site consulting service would greatly enhance the customer degree of satisfaction. However, professionalization of the solutions, being consistent and the number of consultants for the project have no effect on Y Company's satisfaction, which indicates that they should not be considered during the service to Y Company.

\section{Conclusions}

This paper reveals that more than half of requirements of the consulting service of Y Company are must-be requirements. This indicates that these requirements must be delivered during the service. Moreover, there are 4 one-dimensional requirements, which indicates that these requirements are quality enhancer and they can proportionately increase the satisfaction of Y Company when incorporated into the process of consulting service, and their absence would greatly dissatisfy customers. Only one requirement is "attractive", which shows that though its absence in the future product may not cause dissatisfaction, its presence on the other hand will delight Y Company greatly. A careful look at the Kano analysis also shows that many of the respondents indicated indifference to the re- 
quirements, implying that they do not care whether the requirements are met or unmet. The presence of these features does not trill them and neither does their absence dissatisfy them. Y Company is nonchalant about the features.

Knowing of Y Company's requirements, the consultant firm could provide its service accordingly, which would improve Y Company's satisfaction with less useless effort. In addition, this research could be a reference to other consulting project, which would help other consultant to analyze the requirements of their clients.

\section{References}

[1] Wikipedia. Management Consulting. https://en.wikipedia.org/wiki/Management_consulting

[2] Liu, H. (2009) A Study on Customer Satisfaction of Management Consulting Enterprises Based on Fuzzy Comprehensive Evaluation. Master Thesis, Tianjin University, Tianjin.

[3] Zhang, Z. (2013) Requirements Change Management of Information System. Master Thesis, University of Chinese Academy of Sciences, Beijing.

[4] Jia, J. (2014) The Research on the Impact of Requirement Change in Software Project Based on System Dynamics. Master Thesis, Nankai University, Tianjin.

[5] Yang, G. (2015) Requirement Change Management in Small Size Software Projects. Master Thesis, Shanghai Jiao Tong University, Shanghai.

[6] Homburg, C., Wieseke, J. and Bornemann, T. (2013) Implementing the Marketing Concept at the Employee-Customer Interface: The Role of Customer Need Knowledge. Journal of Marketing, 73, 64-81. https://doi.org/10.1509/jmkg.73.4.64

[7] Hussain, A., Mkpojiogu, E.O.C. and Mohmad Kamal, F. (2015) Eliciting User Satisfying Requirements for an E-Health Awareness System Using Kano Model. 14th WSEAS International Conference on Applied Computer and Applied Computational Science, Kuala Lumpur.

[8] Nascimento, P., Aguas, R., Schneider, D. and de Souza, J. (2012) An Approach to Requirements Categorization Using Kano's Model and Crowds. Proceedings of 2012 ICSCWD of the IEEE, Wuhan, 23-25 May 2012, 387-392.

[9] Kano, N., Seraku, N., Takahashi, F. and Tsuji, S. (1984) Attractive Quality and Must-Be Quality. Journal of the Japanese Society for Quality Control, 41, 39-48.

[10] Supply Chain Opz. (2015) How to Use Kano Model for Requirement Assessment. http://www.supplychainopz.com/2013/02/kano-model.html

[11] Zhai, L.L., Hong, L.F. and Sun, Q.Y. (2011) Research on Requirement for HighQuality Model of Extreme Programming. International Conference on Information Management, Shenzhen, 26-27 November 2011, 518-522. https://doi.org/10.1109/iciii.2011.132

[12] Berger, C., Blauth, R., Boger, D., Bolster, C., Burchill, G., DuMouchel, W., Pouliot, F., Richter, R., Rubinoff, A., Shen, D., Timko, M. and Walden, D. (1993) Kano's Methods for Understanding Customer-defined Quality. Center for Quality Management Journal, 4, 3-36.

[13] He, Y. (2009) Analysis of Management Consulting Service Quality and Customer Satisfaction. Enterpriser World, 2, 54-55.

[14] Wu, J., Du, Y., Ke, H. and Ke, D. (2016) Research on the Influencing Mechanism of Whole Process Cost Consultation to Customer Satisfaction under the Internet Thinking. Science and Technology Management Research, 18, 206-212. 
Submit or recommend next manuscript to SCIRP and we will provide best service for you:

Accepting pre-submission inquiries through Email, Facebook, LinkedIn, Twitter, etc. A wide selection of journals (inclusive of 9 subjects, more than 200 journals)

Providing 24-hour high-quality service

User-friendly online submission system

Fair and swift peer-review system

Efficient typesetting and proofreading procedure

Display of the result of downloads and visits, as well as the number of cited articles Maximum dissemination of your research work

Submit your manuscript at: http://papersubmission.scirp.org/

Or contact ajibm@scirp.org 